\title{
ANALYSIS OF PHYSICS LABORATORY MANAGEMENT AT THE NORTHERN REGION OF MAKASSAR'S STATE SENIOR HIGH SCHOOLS BY STANDARD OF FACILITIES AND INFRASTRUCTURE
}

\author{
Santih Anggereni*1, Muh. Syihab Ikbal ${ }^{2}$ \\ 1,2 Physics Education Department, Tarbiyah and Teacher Training Faculty, UIN Alauddin Makassar \\ *Correspondence address: santih.anggereni@uin-alauddin.ac.id
}

Accepted: October $7^{\text {th }}, 2017$. Approved: March $8^{\text {th }}, 2018$. Published: April $28^{\text {th }}, 2018$

\begin{abstract}
This research is descriptive research that aims to know: 1). Description of physics laboratory management related to the layout based on the standard of facilities, 2). The description of the management of physics-related physics laboratory based on the standard of facilities, and 3). Description of the management of the physics laboratory related to safety and health based on the standard of facilities and infrastructure. The population of this research was six state senior high schools (SMAN) in the north region of Makassar. Three samples were obtained by purposive sampling. The results Showed that the management of the layout of the physics had met the standard. Spatial Management of the laboratories was categorized as less appropriate with the standards. Occupational Health and safety (OHS) is categorized as less appropriate with the standards. Based on the results obtained it can be concluded that only in the aspect of the management of the physics laboratories' layout is in line with the regulation of the Ministry of National Education No.24, 2007.
\end{abstract}

(C) 2018 Physics Education, UIN Raden Intan, Lampung, Indonesia

Keywords: layout management, physics laboratory, spatial management, work safety

\section{INTRODUCTION}

Physics is a science that requires observations and measurements made through experiments. Observation of natural phenomena is done by observing and analyzing the factors of cause and effect that interrelate and affect each other. In general, natural phenomena do not provide an opportunity to analyze the effects experienced. This can be overcome by experimenting where various influences are designed beforehand, and the desired state is controlled as well. Experiments take a very important role in the development of modern science and place the importance of working in laboratories for students and researchers (Sani, 2012).

One of the prerequisites in learning or practice of science in laboratory utilization. Therefore, it is necessary to have a good management system or science laboratory management.
Laboratory management has an important role in realizing the effectiveness of science learning (Novianti, 2011). A laboratory is a place where experimental and research activities are conducted. This place can be a closed or open room (Mastika, Adnyana, \& Setiawan, 2014). The Regulation of the Ministry of National Education no. 24 of 2007, described the laboratory equipment standard and infrastructure that must be considered by the educational units in managing the laboratory. The standard in question is about the layout, spatial layout, and safety in the laboratory.

The existence of science laboratories in the First and Secondary Schools play a role in supporting the teaching and learning process in the field of science through the understanding of natural phenomena as a result of observations that could produce Students who are able to do the analytical, critical, and creative 
thinking. The procurement of science tools in schools plays a role to increase the laboratory's efficiency in accordance with the progress of Science and Technology (Darsana, Sadia, \& Tika, 2013).

As a part of science learning, physics learning also requires a laboratory. This physics laboratory is expected to be a place for the development of students' mindset and scientific attitude. In the laboratory, students and teachers conduct the learning in the form of practicum and research. Teachers can use laboratory facilities for practicum activities, where practicum activities are an integral part of teaching and learning activities. The laboratory becomes the scope of the National Education Standards concerning the minimum criteria required to support the learning process including technology and communication (Imastuti, Wiyanto, \& Sugianto, 2016).

Anwar states that the implementation of Physics practice in the field now still faces many obstacles (Anwar, E., 2014). Problems faced by teachers in conducting practicum such as lack of equipment, materials, and lack of knowledge and skills of the teachers in managing practicum activities. In addition, the absence of assistants who assist teachers and too many students make it difficult to regulate the process of activities.

According to Novianti, the utilization of science laboratory will be maximized if it is supported by management or system that is in accordance with the standard set in the Regulation of the Ministry of National Education (Novianti, 2011). As the result of Yaman's research confirms that science laboratories should be managed and empowered into an ideal laboratory, for instance, the condition of science laboratory in SMPN 7 Kubung produced very far from ideal conditions (less appropriate with the Regulation of the Ministry of National Education) (Yaman, 2016). It requires a competent Head of Laboratory personality, social, managerial, and professional ability in managing laboratory, so that laboratory can be functioned optimally. The accuracy of management will have an impact on the success of science learning, so it is necessary to analyze the management of science laboratories conducted in schools, especially in his study that was focused on the competence of the laboratory managers themselves.

Based on preliminary observations, schools in the northern region of Makassar have physics laboratories. However, the laboratories at the schools are not used according to its function. There are laboratories that are used as multifunction rooms; in this case, they are used as classrooms and warehouses. In addition, the management of the laboratories' physical layout, equipment's, and materials are not prepared in accordance with their respective characteristics. This state of physics laboratory, as obtained from the observation, certainly gives an impact on the process of physics learning, especially on practical activities.

A study conducted by Ali (2015) on the performance of physics laboratories in Islamic senior high schools in the city of Makassar shows that the performance of the head of the laboratory of schools is in a low category (Ali, 2015). However, the study did not look at the arrangement or management of laboratory space, laboratory layout and the operational health and safety (OHS).

Based on the description, it was deemed necessary to conduct research under the title "Analysis of Physics Laboratory Management at the Northern Region of Makassar's State Senior High Schools by Standard of Facilities and Infrastructure."

The purpose of this research was to investigate the description of physics laboratory management based on the standard of facilities and infrastructure in terms of layout, spatial layout, and laboratory health and safety. 


\section{METHOD}

This research is quantitative descriptive research. According to Subana, descriptive research is a research that aims to investigate facts, circumstances, variables, and phenomena occurred and then present it as it is (Subana \& Sudrajat, 2011).

The approach used in this research was a direct observation on the object of research related to the layout, spatial layout, and the aspects of occupational safety and health.

The population of the study was all State Senior High Schools located in the northern region of Makassar. Three samples were obtained through purposive techniques, namely SMAN 18 Makassar, SMAN 21 Makassar and SMAN 22 Makassar. The three schools sampled are schools that have unintegrated science laboratories (Physics, Biology, and Chemistry).

The instruments used in this research were 1) observation sheet, used to see the suitability of laboratory with the Regulation of the Ministry of Education in terms of management of layout, spatial, tools and laboratory materials, 2) interview guides, used to obtain additional information from the school about laboratory management, and 3) documentation, used to document the findings obtained during the research of the aspects studied.

The data obtained was processed by descriptive analysis, by using the formula of average and the formula of proportion, as stated in Siregar, as follows (Siregar, 2014):

$$
\bar{X}=\frac{\sum X}{N}
$$

$$
\begin{aligned}
& \bar{X}=\text { Average Score } \\
& X=\text { Obtained Score } \\
& \mathrm{N}=\text { Observed Aspects }
\end{aligned}
$$

To determine the percentage of categories used the formula proportion as follows:
$P=\frac{f}{N} \times 100 \%$

$$
\mathrm{P}=\text { Percentage }
$$

$f=$ Frequency

$N=$ Number of Sample

The range of values used to define the laboratory management category follows the value range of laboratory as follows:

Table 1. Categorization of laboratory management

\begin{tabular}{cc}
\hline Range & Category \\
\hline $91-100$ & Highly Appropriate \\
$76-90$ & Appropriate \\
$61-75$ & Quite appropriate \\
$51-60$ & Less Appropriate \\
$0-50$ & Inappropriate \\
\hline
\end{tabular}

\section{RESULT AND DISCUSSION}

\section{RESULT}

\section{a. Description of Physics laboratories Layout Management}

Data on research results related to the management of physics laboratories for layout aspects can be seen in the following table:

Table 2. Recapitulation of physics laboratory management data for layout aspect

\begin{tabular}{clc}
\hline No & Schools & Score \\
\hline 1 & SMAN 18 Makasar & 80 \\
2 & SMAN 21 Makasar & 90 \\
3 & SMAN 22 Makasar & 80 \\
\hline \multicolumn{2}{l}{ Average } & 80 \\
\hline
\end{tabular}

Based on the data in table 2 , the description of physics lab management for the layout aspect can be categorized based on the following table 3 :

Table 3. Category of Physics laboratory management for layout aspect

\begin{tabular}{cccc}
\hline Range & $\boldsymbol{f}$ & Category & $\boldsymbol{\%}$ \\
\hline $91-100$ & 0 & $\begin{array}{c}\text { Highly } \\
\text { Appropriate }\end{array}$ & 0 \\
$76-90$ & 3 & Appropriate & 100 \\
\hline
\end{tabular}




\begin{tabular}{cccc}
\hline Range & $\boldsymbol{f}$ & Category & $\%$ \\
\hline $61-75$ & 0 & $\begin{array}{c}\text { Quite } \\
\text { Appropriate }\end{array}$ & 0 \\
$51-60$ & 0 & $\begin{array}{c}\text { Less } \\
\text { Appropriate }\end{array}$ & 0 \\
$0-50$ & 0 & Inappropriate & 0
\end{tabular}

Based on table 3, recapitulation of physics lab layout category, the average score of management of physics lab layout of the State Senior High schools at the northern area of Makassar was in good category the percentage of $100 \%$, so it can be concluded that the layout of physics laboratory of the State Senior High schools in the northern area of Makassar was in accordance with standard of the Regulation of the Ministry of National Education No.24 of 2007 (Depdiknas, 2007).

\section{b. The Description of Physics Laboratory Management on Spatial aspects}

Data of research results related to the management of physics laboratory is in the following table:

Table 4. Recapitulation of physics laboratory management data for spatial aspects

\begin{tabular}{|c|c|c|c|c|c|}
\hline Schools & 1 & 2 & 3 & Total & Score \\
\hline I & 26 & 84 & 14 & 124 & 60 \\
\hline II & 28 & 120 & 13 & 161 & 78 \\
\hline III & 20 & 87 & 15 & 122 & 59 \\
\hline \multicolumn{5}{|c|}{ Average } & 66 \\
\hline
\end{tabular}

$$
\begin{array}{ll}
\text { Explanation: } \\
\mathrm{I} \quad=\text { SMAN 18 Makassar } \\
\mathrm{II}=\text { SMAN 21 Makassar } \\
\mathrm{III}=\text { SMAN 22 Makassar } \\
1 \text { = Spatial Inventories } \\
2 \text { = Learning Equipment } \\
3 \text { = Terms of the condition of facilities and } \\
\quad \text { infrastructure }
\end{array}
$$

\begin{tabular}{|c|c|c|c|}
\hline Range & $f$ & Category & $\%$ \\
\hline 91-100 & 0 & $\begin{array}{c}\text { Highly } \\
\text { Appropriate }\end{array}$ & 0 \\
\hline $76-90$ & 1 & Appropriate & 33 \\
\hline $61-75$ & 0 & $\begin{array}{c}\text { Quite } \\
\text { Appropriate }\end{array}$ & 0 \\
\hline $51-60$ & 2 & $\begin{array}{l}\text { Less } \\
\text { Appropriate }\end{array}$ & 67 \\
\hline $0-50$ & 0 & Inappropriate & 0 \\
\hline
\end{tabular}

Based on the data in table 4 , the description of physics lab management for spatial aspects can be categorized based on the following table 5:
Table 5. Category of Physics laboratory management for spatial aspects

Based on table 5, the recapitulation of spatial aspects of physics laboratory, SMAN 18 Makassar, and SMAN 22 Makassar was in quite appropriate category and SMAN 21 Makassar is in the appropriate category. So, it can be concluded that the physics laboratory spatial aspects of the State Senior High schools at the northern area of Makassar was in the category of quite appropriate with a percentage of $33 \%$ and $67 \%$ in the medium category, which is presented in the following pie diagram:

\section{c. The Description of management of Physics Laboratory in the aspect of Occupational Safety and Health.}

Data on research results related to the management of physics laboratory for aspects of occupational safety and health (K3) can be shown in the following table:

Table 6. Recapitulation of physics laboratory management data for safety and health aspects (K3)

\begin{tabular}{clc}
\hline No & Schools & Score \\
\hline 1 & SMAN 18 Makasar & 60 \\
2 & SMAN 21 Makasar & 48 \\
3 & SMAN 22 Makasar & 63 \\
\hline \multicolumn{2}{c}{ Average } & 57 \\
\hline
\end{tabular}

Based on the data in table 6 , the description of physics laboratory management for occupational safety and 
health (K3) can be categorized based on the following table 7 :

Table 7. Category of Physics Laboratory for Occupational Safety and Health (K3)

\begin{tabular}{cccc}
\hline Range & $\boldsymbol{f}$ & Category & $\%$ \\
\hline $91-100$ & 0 & $\begin{array}{c}\text { Highly } \\
\text { Appropriate }\end{array}$ & 0 \\
$76-90$ & 0 & Appropriate & 0 \\
$61-75$ & 1 & Quite Appropriate & 34 \\
$51-60$ & 1 & Less Appropriate & 33 \\
$0-50$ & 1 & Inappropriate & 33 \\
\hline
\end{tabular}

Based on table 7, the recapitulation of occupational safety and health category of physics laboratory, SMAN 18 Makassar was in the medium category with the percentage of 33\%, SMAN 21 Makassar was in Less Appropriate category with the percentage of $33 \%$ and SMAN 22 was in Quite an Appropriate category with the percentage of $33 \%$.

\section{DISCUSSION}

The results obtained from the research of the State Senior High schools at the northern area of Makassar, related to laboratory management, showed that for the management of the spatial layout aspects of the studied schools has been in accordance with the standard of facilities and infrastructure. For the management of spatial and occupational safety (K3), only 1 out of 3 schools that were in accordance with the standards, while the other two schools were less appropriate with the standards.

Based on the results obtained it can be concluded that only in the aspect of the management of physics laboratory layout that was appropriate with the Regulation of the Ministry of National Education No.24 of 2007 (Depdiknas, 2007).

Lack of management on the spatial aspects and laboratory safety due to the lack of involvement of the school in running the standard facilities and Infrastructure. The number of activities and works as directed in the school curriculum is one of the factors that inhibit the lack of attention from the school, in this case, the laboratory personnel to manage the laboratory effectively. In addition, a solid teaching schedule causes laboratory personnel does not have enough time to manage their laboratories.

Some of the above obstacles reinforced by the results of research by Imastuti states that the conditions of laboratory management in schools due to the absence of management personnel and the teachers are busy teaching in the class, so that laboratory management is not running optimally. In order for the laboratories' sustainability, efficiency, and utility to be maintained, the laboratory needs to be well managed; one part of the management is the staff or the laboratory personnel (Imastuti et al., 2016).

Katili adds that other inhibiting factors are the budget for equipment purchases and the replacement of damaged equipment budgeted by schools is still too small to meet the standard of facilities and infrastructure as set out in the Regulation of the Ministry of National Education no. 24 of 2007 (Katili, Sadia, \& K, 2013). Therefore, there are many shortages of laboratory equipment needed in physics learning, and this problem will certainly have an impact on the less optimal of the physics learning process and also contribute to the low average of student learning outcomes.

The Regulation of the Ministry of National Education no. 24 of 2007 contain a detailed explanation of the optimal laboratory management. The rules describe the standard of school facilities and infrastructure, one of which is the physics laboratory. Based on this standard, then the school physics laboratory should be done optimally. Istiqomah added through the results of her research that for the management of physics laboratories to be good then it needs to consider several factors, namely (1) the availability of good practicum equipment, (2) physics teacher 
readiness, and (3) laboratory's personnel readiness (Istiqomah \& Kusumaningtyas, 2016).

The result of this research is in line with the research conducted Puspita which shows that the average quantity and quality of equipment, furniture, and physics laboratory rooms of state senior high schools in Malang is $55.2 \%$, which is not appropriate with the Regulation of the Ministry of National Education Number 24 Year 2007 about the standard of facilities and infrastructure of high school laboratory (Puspita, Masjkur, \& Muhardjito, 2016).

Based on the description, then the school should give enough attention to the management of the laboratory. This is so that the implementation of physics learning in schools can be implemented optimally. A good laboratory will certainly have a good impact on the achievement of the goals required by the curriculum.

\section{CONCLUSIONS AND SUGGESTIONS}

Based on the result of the research, it can be concluded that: (1) description of physics laboratory layout management in the State Senior High schools at the northern area of Makassar is appropriate with the standard of facilities and infrastructures of the Regulation of the Ministry of National Education Number 24 the Year 2007; (2) description of physics laboratory management in the State Senior High schools at the northern area of Makassar related to spatial layout is categorized less appropriate with the standard of facilities and infrastructures of the Ministry of National Education Number 24 Year 2007; (3) description of physics laboratory management in the State Senior High schools at the northern area of Makassar related to the Occupational Safety and Health (K3) is categorized less appropriate with the standard of facilities and infrastructures of the Ministry of National Education Number 24 the Year 2007.
The results of this study illustrate the state of physics laboratory management in the State Senior High schools in the northern area of Makassar. They have not described the laboratory conditions in schools located in other areas of Makassar. In addition, the results of this study also focus only on the description of physics laboratories and not in chemical or biological laboratories, so that further research is needed to describe the laboratory conditions in all areas of Makassar.

\section{ACKNOWLEDGMENT}

The researchers' gratitudes belong to the relevant departments for cooperation during the research process, as well as to all parties who have provided input in this research.

\section{REFERENCES}

Ali, M. (2015). Analisis Kinerja Ketenagaan Laboratorium Fisika Madrasah Aliyah Kota Makassar. UIN Alauddin Makassar.

Anwar, E., D. (2014). Pelatihan Pembuatan Alat-Alat Praktikum IPA Fisika Bagi Guru IPA SMP/MTs Swasta Se-Kecamatan Winong Kab Pati. Dimas Jurnal Pemikiran Agama Untuk Pemberdayaan, 14(1), 43-56.

Darsana, I. W., Sadia, I. W., \& Tika, I. N. (2013). Analisis Standar Kebutuhan Laboratorium Kimia dalam Implementasi Kurikulum 2013 pada SMA Negeri di Kabupaten Bangli. Jurnal Pendidikan IPA Indonesia, 4(1), 1-10.

Depdiknas. Permendiknas Nomor 24 tahun 2007 tentang Standar Sarana Dan Prasarana untuk Sekolah Dasar/Madrasah Ibtidaiyah (SD/MI), Sekolah Menengah Pertama/Madrasah Tsanawiyah (SMP/MTs), dan Sekolah Menengah Atas/Madrasah Aliyah (SMA/MA) (2007). Indonesia: Jakarta.

Imastuti, Wiyanto, \& Sugianto. (2016). 
Pemanfaatan Laboratorium dalam Pembelajaran Fisika SMA/MA SeKota Salatiga. Unnes Physics Education Journal, 5(3), 51-58.

Istiqomah, H. F. N., \& Kusumaningtyas, D. A. (2016). Analisis Pengelolaan Peralatan Praktikum Fisika Kelas XI SMA Muhammadiyah 1 Yogyakarta Menggunakan Model Countenance Stake. JRKPF UAD, 3(2), 55-62.

Katili, N. S., Sadia, I. W., \& K, S. (2013). Analisis Sarana dan Intensitas Penggunaan Laboratorium Fisika serta Kontribusinya Terhadap Hasil Belajar Siswa SMA Negeri di Kabupaten Jembrana. E-Journal Program Pascasarjana Universitas Pendidikan Ganesha Program Studi IPA, 3.

Mastika, I. N., Adnyana, I. B. P., \& Setiawan, I. G. N. A. (2014). Analisis Standarisasi Laboratorium Biologi dalam Proses Pembelajaran di SMA Negeri Kota Denpasar. E-Journal Program Pascasarjana Universitas Pendidikan Ganesha Program Studi IPA, 4.
Novianti, N. R. (2011). Kontribusi Pengelolaan Laboratorium dan Motivasi Belajar Siswa terhadap Efektivitas Proses Pembelajaran. Jurnal Pendidikan MIPA UPI Edisi Khusus, 1, 158-166.

Puspita, W. I., Masjkur, K., \& Muhardjito. (2016). Analisis Pengelolaan Laboratorium Fisika SMA Negeri di Kabupaten Malang. In Seminar Nasional Jurusan Fisika FMIPA UM. Malang: Universitas Negeri Malang. 37-42.

Sani, R. A. (2012). Pengembangan Laboratorium Fisika. Medan: Unimed Press.

Siregar, S. (2014). Statistik Parametrik untuk Penelitian Kuantitatif. Jakarta: Bumi Aksara.

Subana, M., \& Sudrajat. (2011). DasarDasar Penelitian Ilmiah. Bandung: Pustaka Setia.

Yaman. (2016). Pengoptimalan Peran Kepala Labor dalam Menunjang Pembelajaran IPA di SMPN 7 Kubung. Jurnal Penelitian Guru Indonesia-JPGI, 1(1), 63-71. 